\title{
WHITMAN AND THE SISTER ARTS
}

\author{
RUTH L. BOHAN
}

LATE IN LIFE, in conversation with Horace Traubel, Whitman noted that during the crucial years immediately preceding the 1855 publication of Leaves of Grass he had found more to nurture and sustain his revisionist poetics in the company of artists than writers. ${ }^{1}$ Fully one-third of Whitman's journalistic writings in the 1840 s and early 1850 s included discussions of the visual arts, a percentage that significantly increased as the publication of Leaves of Grass neared. ${ }^{2}$ Friendships and professional alignments during these years stimulated Whitman's interest in the mutuality between the verbal and visual arts. Particularly crucial were Whitman's associations with poet, editor, and noted arts patron William Cullen Bryant and with Bryant's associate, sculptor Henry Kirke Brown. Both Bryant and Brown actively endorsed the ancient Horatian doctrine of ut pictura poesis - like painting so like poetry. Whitman, too, was deeply involved in the sister arts ideal and, like many mid-century poets appropriated its conventions in both his poetry and prose writings. But Whitman also transfigured those traditions in a number of insightful and challenging ways essential to his revisionist poetics. This essay explores both Whitman's conformity to and reconfiguration of the centuries-old celebration of the reciprocity between the verbal and visual arts.

Even more than Gabriel Harrison, the photographer, playwright, and Free Soil Democrat who took the famous daguerreotype with which Whitman launched his new book of poetry, William Cullen Bryant stimulated Whitman's interart sensibilities. Throughout his long and distinguished career, Bryant regularly sought out the company of practicing artists, championed their cause on the pages of his newspaper, the New York Evening Post, and helped launch several of this country's leading arts organizations, including the National Academy of Design and the American Art-Union. About the time he and Whitman met, Bryant was President of the American Art-Union, the country's largest subscription-based arts organization and a major force in the exhibition and marketing of works by American artists. Among Bryant's closest friends were Thomas Cole, founder of the Hudson River School of landscape painters, and Asher B. Durand, whose painting, Kindred Spirits (1849) hung proudly in Bryant's home. The painting, which Whitman undoubt- 
edly saw, has Bryant and Cole silhouetted against a dramatic precipice in the Catskill Mountains in a glorious celebration of their mutual commitment to nature as the source of moral and artistic inspiration. ${ }^{3}$

Whitman characterized Bryant as "a man to become attach'd to" and shared the older man's tastes in art, especially his fondness for landscape painting and portraiture. Whitman particularly delighted in Bryant's accounts of his visits with American artists while traveling in Europe. ${ }^{4}$ Among those whose studios Bryant visited were Hiram Powers, noted for his phenomenally popular sculpture, The Greek Slave (1843), and Emanuel Leutze, who would become famous for his painting of Washington Crossing the Delaware (1851). ${ }^{5}$ Although he never traveled abroad, Whitman, like Bryant, sought out the company of artists and owned works imbued with the sister arts ideal, including an engraving of Jesse Talbot's Christian and the Cross, Pilgrim's Progress (1847), based on John Bunyan's 1678 verbal allegory. Among Whitman's earliest artist friends was Charles Heyde, a landscape painter who would shortly marry Whitman's sister, Hannah. Although Whitman would later revile Heyde, calling him, among other things, "a damned lazy scoundrel," in the early 1850 s he thought highly enough of him to invite Bryant to join him on a visit to Heyde's studio. ${ }^{7}$ Whitman was also friends with Walter Libbey, a specialist in portraits and rural genre subjects. Whitman once even commented on the genre potential of his own life experiences, finding in his 1848 travels through the Allegheny Mountains en route to New Orleans "first rate scenes for an American painter." 8

Like Bryant, Whitman was personally active in efforts to promote artists' work, particularly in Brooklyn. He devoted considerable energy to supporting the activities of the Brooklyn Art Union, the Brooklyn counterpart to Bryant's American Art-Union. On the basis of a series of articles he wrote, including one in Bryant's New York Evening Post (UPP $1: 236-238$ ), Whitman was invited to present the keynote address at the Brooklyn Art Union's first distribution of prizes on March 31, $1851 .^{9}$ In it Whitman peppered his remarks with quotes and indirect references to Emerson, the Bible, Ruskin, Shakespeare and Socrates, among others. Still, it was Bryant who commanded Whitman's strongest sympathy and against whom he was most likely to measure himself. Midway through his remarks Whitman recited several lines from Bryant's "Forest Hymn" and concluded with a lengthy passage from "Resurgemus," one of his own early free-verse poems (UPP 1:241-247). Although Bryant's name was never mentioned, the intention was unmistakable: to pay homage to Bryant, while simultaneously establishing himself as Bryant's heir-apparent-both as poet and as spokesperson for the visual arts in Brooklyn. Shortly thereafter Whitman was nominated to be the organization's first president. Had the Brooklyn Art Union not closed later in the year, Whitman might well have succeeded 
in becoming the William Cullen Bryant of his native Brooklyn.

Like Bryant, Henry Kirke Brown was a member of the Knickerbocker group and a staunch artistic nationalist. Whitman had reviewed Brown's first solo exhibition at the National Academy of Design in 1846 (UPP 1:142-143), although the two probably did not meet until after Brown moved his studio to Brooklyn in 1849. Brown's studio attracted a lively gathering of artists, writers and devoted arts patrons. Regulars included painters Sanford Gifford, Daniel Huntington, William Page, Asher B. Durand and Samuel Colman; sculptors Launt Thompson, John Quincy Adams Ward and Larkin G. Meade; banker and art patron Henry G. Marquand; and William James Stillman, one of the founders of The Crayon, the country's first art journal, which debuted the same year as Whitman's Leaves of Grass. ${ }^{10}$ Together, these individuals constituted a working model of the "close phalanx" of artists "ardent, radical and progressive" that Whitman called for in his article in Bryant's New York Evening Post (UPP 1:237).

Immersion in the Brown circle further stimulated Whitman's sense of the creative affinities between the verbal and visual arts. The group's discussions about what constituted a truly "American" art, their preference for American over European subject matter, their concern with artistic naturalism over the more traditional language of classicism, and their technical challenges to the prevailing norms of their profession served as important visual corollaries for the literary challenges Whitman was beginning to set for himself as a poet.

Midcentury adherents to the sister arts ideal were particularly inclined to exploring in one art form attributes and practices of the other. Poems about paintings or visits to artists' studios abounded, as did paintings based on poems. Bryant's poetry proved particularly attractive to artists. Some twenty-seven artists produced forty works of art giving visual expression to two dozen of Bryant's poems. Asher B. Durand alone completed five paintings on Bryant's poetry. ${ }^{11}$ In similar fashion, Brown's sculpture Ruth gleaning in the field of Boaz was inspired by lines from Keats' "Song of the Nightingale." Whitman, too, engaged in such interart practices. The most well-documented example involved his use of Alfred Jacob Miller's painting, The Trapper's Bride (1845), as the visual basis for the verbal narrative involving "the marriage of the trapper ... [and] a red girl" in "Song of Myself." 12 In both painting and poem a trapper, "drest mostly in skins . . . held his bride by the hand," while "Her father and his friends sat near cross-legged and dumbly smoking, ... moccasins to their feet and large thick blankets hanging from their shoulders." 13

Whitman was even more inclined toward the appropriation of interart terminology, another hallmark of the sister arts. He likened himself to a painter in "To You" ( $L G$ 233-235), described "(what we call poems being merely pictures,)" in "Spontaneous Me" (LG 103), and, in "Song of the Answerer," he grouped the artist with the builder, ge- 
ometer, chemist, anatomist, and phrenologist as those who "underlie the maker of poems, the Answerer" ( $L G$ 170). Whitman's repeated appropriation of visual arts terminology - as when he writes of "Lithographing Kronos" ( $L G 75)$, of "driving the mallet and chisel" in "his roll'd-up sleeves" ( $L G 75)$, or described "These burin'd eyes, flashing to you to pass to future time" in "Out from behind This Mask" ( $L G$ 382) - reverberated in his prose writings as well. In 1862, under the pen name "Velsor Brush," Whitman published a series of articles in the New York Leader which he entitled "City Photographs."14 While the pseudonym derived from the names of two of his ancestors (Louisa Van Velsor and Hannah Brush), its painterly implications recalled Washington Irving's earlier transgenre invention, Geoffrey Crayon. ${ }^{15}$ Like Crayon's The Sketch-Book, Whitman's "City Photographs" series consisted of abbreviated descriptions, character sketches and observations from life, and like Irving Whitman referred to his vignettes as "sketches." By employing the terms "photograph" and "sketch" interchangeably, Whitman made no distinction between the newer, mechanical art-photography-and its more traditional counterparts-drawing and painting. In freely appropriating the terminology of several arts media, Whitman reinforced the ecumenism of his visual arts enthusiasm.

If Whitman subscribed to many of the sister arts ideals, his familiarity with the aesthetic theories of the German philosopher Gotthold Ephraim Lessing cautioned him against the wholesale transcription of individual works of art so popular among many sister arts enthusiasts. Lessing's Laocoön, first published in 1766, challenged accepted notions of the sisterhood of the arts by associating unique properties with each of the arts. Description was the rightful province of the painter, the presentation of progressive motion that of the poet. In order not "to compete with the painter on a point on which they must of necessity be surpassed by him," Lessing urged poets to explore other means than description. ${ }^{16}$ Shortly after the publication of Leaves of Grass, Whitman contrasted his approach with that of his fellow poets:

The theory and practice of poets have hitherto been to select certain ideas or events or personages [he might have added works of art], and then describe them in the best manner they could, always with as much ornament as the case allowed. Such are not the theory and practice of the new poet. He never presents for perusal a poem ready-made on the old models. . . . ${ }^{17}$

For Whitman, the exhibition experience, even more than the isolated work of art, offered exciting possibilities for his revisionist poetics. Whitman regularly reviewed art exhibitions in and around New York, including those of the American Art-Union, the National Academy of Design, and the Brooklyn Art Union. Still, Whitman's initial excursion 
into this genre conformed with standard sister art conventions. "Pictures," written in the early 1850 s, most likely during his association with the Brown group, employs a conceit popular at the time, of representing the imagination as a picture gallery of the mind. ${ }^{18}$ The pictures range from panoramic landscapes and genre scenes to intimate still lifes and portraits, historical subjects, and evocative tales of the imagination. Briefly sketched, each scene represents the verbal equivalent of a work of art, their themes reflective of the range and types of art which filled the exhibition galleries in Brooklyn and Manhattan in the 1840s and 1850 s.

Similar conceits can be found in the work of Whitman's contemporaries. In "Art," Emerson likened his fellow human beings to the statuary in an art gallery. ${ }^{19}$ The minor poet Lily Graham prefaced her 1851 poem, "A Heart-Picture," with an excerpt from one of Percy Bysshe Shelley's poems, which told of "A picture, drawn within the brain, / By Memory's faithful pencil." 20 Bryant was similarly fond of such tropes, writing in 1851 to thank his friend Charles Sedgwick "for some of the finest landscapes in the picture-gallery of my memory, collected during our late pleasant visit to Berkshire."21

In his mature poetry, the exhibition experience found its most telling and creative reenactment in Whitman's catalogues. Here Whitman radically parted company with the sister art conventions of his contemporaries. Whitman was entranced both by the eclectic range of the art exhibited and by the physical characteristics of its display. In the galleries of the American Art-Union (see illustration on back cover) as in other art galleries of the period, whether devoted to paintings or daguerreotypes, works of art were generally "skied," that is hung one above the other until they literally covered the wall from floor to ceiling and side to side. Large works were frequently hung above smaller ones, with their upper edges projecting out several inches from the wall to facilitate viewing. In such a richly eclectic environment, the works seemed almost to bombard the spectator with their unresolved juxtapositions of scale, style, and thematic variation. Whitman's catalogues approximate the excitement.and stimulation of the gallery experience. In clear, graphic terms, which arrest the reader's attention by the forceful immediacy of their presentation, the catalogues juxtapose dozens of images of contemporary, historical and imaginary scenes. Encyclopedic in scope, both the gallery displays and their verbal counterparts span continents, centuries, and the open road. Whitman's friend, the naturalist John Burroughs, acknowledged the transgressive and transgenre appeal of Whitman's work when he termed his catalogues "one line genre word paintings" and judged "every line . . . a picture." 22

The visual self-representations which complement, reinforce, and extend the verbal text of Leaves of Grass, beginning with Harrison's 
daguerrean worker-poet, provide additional evidence of Whitman's creative restructuring of the sister arts ideal. In his drive to forge significant transgenre alliances with the visual arts, Whitman constructed and manipulated visual representations of himself to serve as potent visual analogues for the evolving poetic persona of his verse. In striking contrast to his literary colleagues, Whitman projected his "visualist poetry" into the actual realm of the visual. ${ }^{23}$ The self-representations which accompany the verbal text of Leaves of Grass enact both Whitman's commitment to the vivifying potential of the pictorial arts and his concern for the dynamic interplay between text and image. They serve as far more than visual representations of the author at various discrete moments of his life. They are instead visual tropes meant to vivify the shifting and often conflicted persona of the verse.

Following the decline of his health in the early 1870s, Whitman reinvented the jaunty Harrison representation. When positioned opposite the title page in the 1855 edition, it had been called upon to evoke the robust and transgressive quality of the whole of Leaves of Grass. In 1876 it was relocated to a position opposite the commencement of the poem, "Walt Whitman," since retitled "Song of Myself," the poet's joyful ode to the time when he was himself "thirty-seven years old [and] in perfect health" ( $L G$ 29). A more contemporary photograph by Frank Pearsall replaced the Harrison opposite the title page. Much had intervened in the twenty years separating these two editions, and now the Harrison worker-poet was no longer a representative trope for the whole of Leaves of Grass. Here and in several subsequent editions, it served primarily as a trope for those aspects of the poetry centered, as Whitman wrote, on "flesh and blood, and physical urge, and animalism" ( $L G 752 \mathrm{n})$.

A full assessment of the shifting parameters of this text-image paradigm as it is revealed throughout the various editions of Leaves of Grass published during Whitman's lifetime is not possible in this brief essay. Suffice it to say that Whitman continued to explore the expressive potential of the growing number of self-representations made of him by his artist friends throughout the remainder of his life. Long after the waning of his associations with the Brown group, Whitman continued to seek out the company of artists and to explore ways to translate the visceral effects of his viewing experiences into the verbal means of his art. Whitman remained committed to the sister arts ideal, albeit on his own terms and in ways that challenged the conventions under which it has traditionally been understood. In his later years and especially following his death in 1892, Whitman's life would once again parallel Bryant's as artists as diverse as Thomas Eakins, Marsden Hartley, and Joseph Stella-representing the diverse arenas of Realism, Expressionism, and Cubo-Futurism - devised ways to translate aspects of Whitman's verse into the visual medium of their art. This poet who prided 
himself on being "Both in and out of the game and watching and wondering at it" ( $L G 32)$ would enjoy a legacy of unparalleled vitality within the visual arts community in the early twentieth century. Just as Whitman had boldly reconfigured the transgenre appeal of the sister arts, so the artists who sought him out years after his death would extend that appeal well into the next century.

University of Missouri-St. Louis

\section{NOTES}

1 With Walt Whitman in Camden, ed. Horace L. Traubel (1907; rpt. New York: Rowman and Littlefield, 1961), 2:502.

2 Ruth L. Bohan, “The Gathering of the Forces': Walt Whitman and the Visual Arts in Brooklyn in the 1850s," Walt Whitman and the Visual Arts, ed. Roberta K. Tarbell and Geoffrey M. Sill (New Brunswick: Rutgers University Press, 1992), 2.

3 On Bryant's involvement in the visual arts, see especially David Shapiro, "William Cullen Bryant and the American Art Union," William Cullen Bryant and His America (New York: AMS Press, 1983), 85-95; Holly Joan Pinto, William Cullen Bryant and the Hudson River School of Landscape Painting (Roslyn, NY: Nassau County Museum of Fine Art, 1981); William Cullen Bryant II, "Poetry and Painting: A Love Affair of Long Ago," American Quarterly 22 (Winter 1970), 859-882; James T. Callow, Kindred Spirits: Knickerbocker Writers and American Artists, 1807-1855 (Chapel Hill: University of North Carolina Press, 1967); and Donald A. Ringe, "Kindred Spirits: Bryant and Cole," American Quarterly 6 (Fall 1954), 233-244.

4 Prose Works 1892, ed. Floyd Stovall (New York: New York University Press, 1963), $1: 166$.

5 William Cullen Bryant, II, and Thomas G. Voss, eds., The Letters of William Cullen Bryant (New York: Fordham University Press, 1977), 2:409-413.

6 With Walt Whitman in Camden, ed. Jeanne Chapman and Robert MacIsaac (Carbondale: University of Southern Illinois Press, 1992), 7:23.

7 Katherine Molinoff, Some Notes on Whitman's Family (New York: Comet Press, 1941), 7 and 24-43. In 1852, the year he married Hannah Whitman, Heyde gave 106 Myrtle Avenue, the Whitman family residence, as his address for the annual National Academy of Design exhibition.

8 The Uncollected Poetry and Prose of Walt Whitman, ed. Emory Holloway (New York: Doubleday, Doran, 1921), 1:185-86. Hereafter abbreviated UPP.

9 Whitman also praised the Brooklyn Art Union in "Works of Beauty and TalentThe New Art Union of Brooklyn," Brooklyn Daily Advertiser (April 4, 1850), and "Brooklyn Art Union-Walter Libbey-A Hint or Two on the Philosophy of Painting," Brooklyn Daily Advertiser (December 21, 1850).

10 Lewis I. Sharp, fohn Quincy Adams Ward: Dean of American Sculpture (Newark: University of Delaware Press, 1985), 30-31.

11 Bryant, II, "Poetry and Painting: A Love Affair of Long Ago," 872.

12 See Edgeley W. Todd, "Indian Pictures and Two Whitman Poems," The Huntington Library Quarterly 1 (November 1955), 1-5. 
13 Leaves of Grass, Comprehensive Reader's Edition, ed. Harold W. Blodgett and Sculley Bradley (New York: New York University Press, 1965), 37. Hereafter abbreviated $L G$.

14 See Charles I. Glicksberg, Walt Whitman and the Civil War (Philadelphia: University of Pennsylvania Press, 1933).

15 Washington Irving was a close friend of Bryant's and a member of the Knickerbocker group. Whitman scholars have consistently ignored the name's visual art referent to focus instead on the familial connections.

16 Whitman read and heavily annotated J. D. Whelpley's article, "Lessing's Laocoön: The Secret of Classic Composition in Poetry, Painting, and Statuary," in The American Whig Review 37 (January 1851), 17-26. Whitman's copy of the article's final six pages is in the Trent Collection at Duke University. I wish to thank J. Samuel Hammond for making this available to me.

17 In Re Walt Whitman, ed. Horace L. Traubel, Richard Maurice Bucke, and Thomas B. Harned (Philadelphia: David McKay, 1893), 31.

18 Emory Holloway, Pictures: An Unpublished Poem of Walt Whitman (New York: June House; London: Faber \& Guyer, 1927).

19 Ralph Waldo Emerson, Essays by Ralph Waldo Emerson (New York: Harper and Row, 1951), 251.

20 Lily Graham, “A Heart-Picture," The Knickerbocker 38 (July 1851), 59.

21 Quoted in Parke Godwin, A Biography of William Cullen Bryant (New York: Russell \& Russell, 1883), 2:55.

22 John Burroughs, Whitman: A Study (Boston and New York: Houghton Mifflin Co., 1904), 143, 139.

23 James Dougherty, Walt Whitman and the Citizen's Eye (Baton Rouge and London: Louisiana State University Press, 1993), 1. 